\title{
MENINGKATKAN HASIL BELAJAR IPS SISWA \\ DENGAN MENGGUNAKAN METODE PETA KONSEP \\ DI KELAS V SD NEGERI 028 KUBANG JAYA
}

\author{
Syamsul Bahar \\ Syamsulbahar1967@gmail.com \\ SD Negeri 028 Kubang Jaya
}

\begin{abstract}
This research is motivated by the low learning outcomes of social science students in class V of SD Negeri 028 Kubang Jaya. The purpose of this study is to improve students' social studies learning outcomes by applying the concept map learning model. The design of this research is classroom action research consisting of two cycles. Each cycle consists of four stages such as planning, implementing, observing, and reflecting. The results of the study showed that, judging from the basic scores of students, students who completed by 11 people (44\%) and incomplete as many as 14 people (56\%). From the results of the first cycle of the first cycle of daily tests, there were 18 students (72\%) complete and 7 students (28\%) incomplete. Whereas in the second cycle of the second cycle of daily tests, there were 22 students (88\%) complete and 3 students (12\%) incomplete. From these results, the researcher can conclude that by applying the concept map method it can improve the learning outcomes of social science fifth grade students of SD Negeri 028 Kubang Jaya.
\end{abstract}

Keywords: concept map, social studies learning outcomes

\section{ABSTRAK}

Penelitian ini dilatarbelakangi oleh masih rendahnya hasil belajar IPS siswa di kelas V SD Negeri 028 Kubang Jaya. Tujuan penelitian ini adalah untuk meningkatkan hasil belajar IPS siswa dengan menerapkan model pembelajaran peta konsep. Desain penelitian ini merupakan penelitian tindakan kelas yang terdiri dari dua siklus. Setiap siklus terdiri dari empat tahapan seperti perencanaan, pelaksanaan, pengamatan, dan refleksi. Adapun hasil penelitian menunjukan bahwa, dilihat dari skor dasar siswa, siswa yang tuntas sebesar 11 orang (44\%) dan tidak tuntas sebanyak 14 orang (56\%). Dari hasil penilaian siklus I ulangan harian siklus I, siswa yang tuntas sebanyak 18 orang siswa (72\%) dan tidak tuntas sebanyak 7 orang siswa (28\%). Sedangkan pada siklus II ulangan harian siklus II, siswa yang tuntas sebanyak 22 orang ( $88 \%$ ) dan yang tidak tuntas sebanyak 3 orang (12\%). Dari hasil ini, dapat peneliti simpulkan bahwa dengan menerapkan metode peta konsep dapat meningkatkan hasil belajar IPS siswa kelas V SD Negeri 028 Kubang Jaya.

Kata Kunci: Peta Konsep, Hasil Belajar IPS

\begin{tabular}{|c|c|c|}
\hline Submitted & Accepted & Published \\
\hline 01 September 2019 & 15 September 2019 & 23 September 2019 \\
\hline
\end{tabular}

\begin{tabular}{|l|c|c|c|c|}
\hline Citation & $:$ & Bahar, S. (2019). Meningkatkan Hasil Belajar IPS Siswa dengan Menggunakan Metode Peta Konsep di Kelas V SD \\
& $\begin{array}{l}\text { Negeri 028 Kubang Jaya. Jurnal PAJAR (Pendidikan dan Pengajaran), 3(5), 1144-1152. DOI: } \\
\text { http://dx.doi.org/10.33578/pjr.v3i5.7892. }\end{array}$ \\
\hline
\end{tabular}

*Copyright (C) 2019 Jurnal PAJAR (Pendidikan dan Pengajaran)

Publish by PGSD FKIP Universitas Riau, Pekanbaru, Indonesia

\section{PENDAHULUAN}

Keberhasilan pendidikan dipengaruhi oleh banyak faktor, diantaranya adalah: faktor lingkungan guru, proses pembelajaran, materi, kurikulum dan lain-lain. Kurikulum adalah seperangkat rencana dan pengaturan mengenahi isi dan bahan pelajaran serta cara yang digunakan sebagai pedoman penyelenggaraan belajar mengajar (UU Sistem Pendidikan Nasional No. 20 tahun 2003).
Kurikulum Tingkat Satuan Pendidikan sebagai kurikulum yang ditawarkan diharapkan akan memberikan kompetensi sesuai dengan tingkat pendidikan yang akan dicapai. Menurut Permendiknas No 22 tahun 2006 tentang Standar Isi, prinsip pelaksanaan kurikulum di setiap satuan pendidikan menegakkan lima pilar belajar, yaitu: (1) Belajar untuk beriman dan bertakwa kepada Tuhan Yang Maha Esa; (2) 
Belajar untuk memahami dan menghayati; (3) Belajar untuk mampu melaksanakan dan berbuat secara efektif; (4) Bealajar untuk hidup bersama dan berguna bagi orang lain; dan (5) Belajar untuk membangun dan menemukan jati diri melalui proses pembelajaran yang aktif, kreatif, efektif, dan menyenangkan.

Dalam proses pembelajaran khususnya IPS, guru sebagai pengajar dan siswa sebagai subjek belajar, diharapkan terdapat hubungan timbal balik dalam hal pengetahuan, kemampuan, sikap, agar proses belajar mengajar dapat berlangsung dengan efektif dan efisien. Para ilmuan diharapkan agar mengembangkan berbagai pengetahuan, misalnya metode, media, strategi dalam mengajar dan ilmu-ilmu lain yang dapat menunjang proses pembelajaran tersebut.

Menurut Khoir (2012) IPS adalah salah satu mata pelajaran di tingkat sekolah dasar pada hakikatnya merupakan suatu integrasi utuh dari disiplin ilmu-ilmu sosial dan disiplin ilmu lain yang relevan sebagai tujuan pendidikan. Mata pelajaran IPS berperan untuk mengfungsionalkan dan merealisasikan ilmu-ilmu yang bersifat teoritik ke dalam dunia kehidupan nyata di masyarakat, dengan kata lain bahwa IPS secara general, mencakup upaya untuk mengembangkan kemampuan pengetahuan, keterampilan, nilai, dan sikap siswa secara utuh.

Upaya meningkatkan hasil belajar IPS, diharapkan siswa memiliki kemampuan berfikir kritis, kreatif, dan inovatif yang sangat baik bagi pengembangan diri, intelektual, dan sosialnya. Dalam mewujudkan hal tersebut, maka diperlukan pembaharuan dalam pembelajaran IPS. IPS merupakan bagian dari ilmu sosial, keberadaan IPS dalam struktur program pembelajaran di SD sangat penting untuk diajarkan karena IPS memberikan pengetahuan, pembentukan nilai dan sikap serta keterampilan kepada siswa secara langsung berinteraksi dengan lingkungan yang ada di sekitarnya.

Selama ini pembelajaran IPS di SDN 028 Kubang Jaya yang dilaksanakan cenderung ke arah pembahasan teori yang bersifat khusus (tematik teoritik) dan berdasarkan materi yang ada di dalam buku (text book oriented) sehingga terkesan bahwa bidang ini terdiri dari materi hafalan saja. Sebagai contoh pengamatan yang dilakukan di SD Negeri 028 Kubang Jaya ini kebanyakan guru masih memberi materi tanpa adanya variasi dalam menyampaikan materi pada siswa. Siswa SD Negeri 028 Kubang Jaya mengalami kesulitan untuk mencerna dan tidak dapat mengembangkan interaksi dengan sesamanya sebagai latihan hidup di masyarakat. Di sekolah siswa hanya memperoleh hafalan dengan tingkat pemahaman yang rendah. Siswa hanya tahu bahwa tugasnya adalah mengenal fakta, sementara pemahaman dan mengembangkan interaksi belum dapat mereka kuasai.

Berdasarkan permasalahan ini menyebabkan hasil belajar siswa menjadi rendah. Rendahnya hasil belajar siswa ditandai dengan banyaknya siswa yang belum mencapai KKM yang telah ditetapkan yaitu 65. Dari 25 siswa hanya 11 siswa atau $44 \%$ yang mencapai KKM sedangkan 14 siswa atau $56 \%$ belum mencapai KKM dengan nilai rata-rata kelas sebesar 59,09.

Sejalan dengan pendapat Saifullah (2017) rendahnya hasil belajar IPS siswa disebabkan oleh rendahnya motivasi belajar siswa, kurangnya keingintahuan siswa terhadap pelajaran yang disampaikan oleh guru di kelas, dan hanya sebagian kecil siswa yang mau bertanya ataupun mengajukan pendapatnya. Sedangkan sisanya hanya diam ketika guru menerangkan di depan kelas. Lebih lanjut lemahnya hasil belajar siswa menrut Erita (2017) di sebabkan oleh masih ada siswa yang keluar masuk dalam proses belajar mengajar. Keluar masuknya siswa ini disebabkan oleh pembelajaran yang dilaksanakan guru tidak menarik sehingga membuat siswa bosan. Sedangkan menurut Mukmin (2017) rendahnya hasil belajar siswa disebabkan oleh siswa cenderung belajar sendiri-sendiri, serta pengetahuan yang didapat bukan dibangun sendiri secara bertahap oleh siswa atas dasar pemahaman sendiri melainkan lebih banyak mengharapkan dari guru. Karena siswa jarang menemukan jawaban atas permasalahan atau konsep yang dipelajari.

Guna mengatasi permasalahan tersebut maka peneliti akan mencoba menggunakan metode yang dapat diterima dan mudah dipahami siswa kelas V SD Negeri 028 Kubang Jaya. Metode yang digunakan oleh 
peneliti ialah metode peta konsep yang menarik bagi siswa dengan memberikan beberapa warna pada bagan peta konsep, kreatif dalam mendesain bagan peta konsep, dan inovatif dalam mengembangkan pemikiran serta imajinasi pada siswa itu sendiri, guna meningkatkan hasil belajar siswa pada pembelajaran IPS. Dengan karakteristik anak SD kelas V yang berimajinasi tinggi serta berfikir kreatif, maka metode peta

\section{KAJIAN TEORETIS \\ Pengertian Peta Konsep}

Konsep dapat didefinisikan dengan bermacam-macam rumusan. Salah satunya adalah definisi yang dikembangkan Carrol (Kardi 1997) bahwa konsep yang merupakan suatu abstraksi dari serangkaian pengalaman yang didefinisikan sebagai suatu kelompok obyek atau kejadian. Abstraksi berarti suatu proses pemusatan perhatian seseorang pada situasi tertentu dan mengambil elemen-elemen tertentu, serta mengabaikan elemen yang lain.

Peta konsep merupakan diagram yang dibentuk atau disusun untuk menunjukan pemahaman seseorang tentang suatu konsep atau gagasan yang mempunyai struktur berjenjang dari yang bersifat umum menuju yang bersifat khusus dilengkapi dengan garis-garis penghubung yang sesuai. Peta konsep merupakan cara yang dinamik untuk menangkap butir-butir pokok informasi dalam bentuk proporsi melalui proses belajar alamiah dan berfikir. Peta konsep bukan hanya menggambarkan konsep-konsep yang penting melainkan juga menghubungkan antara konsepkonsep itu. Dalam menghubungkan konsepkonsep itu dapat digunakan dua prinsip, yaitu diferensi progresif dan penyesuaian integratif diferensiasi progresif adalah suatu prinsip penyajian materi dari materi yang sulit dipahami.

Pembuatan suatu peta konsep, siswa dilatih untuk mengidentifikasi ide-ide kunci yang berhubungan dengan suatu topik dan menyusun ide-ide tersebut dalam suatu pola logis. Kadangkadang peta konsep merupakan diagram hirarki, kadang peta konsep itu memfokus pada hubungan sebab akibat. Agar pemahaman terhadap peta konsep lebih jelas, maka dapat dilihat ciri-ciri peta konsep sebagai berikut: konsep ini dirancang semenarik mungkin bagi siswa sehingga dapat mengembangkan kekreatifitasannya dan imajinasinya. Metode peta konsep dapat juga membantu guru dalam mengembangkan materi pelajaran melalui bagan konsep, sehingga siswa lebih tertarik dalam belajar. Melalui bagan konsep siswa juga dapat lebih cepat dalam memahami materi yang disajikan oleh guru.

1. Peta konsep adalah suatu cara untuk memperlihatkan konsep- konsep dan proposisiproposisi suatu bidang studi, apakah itu bidang studi fisika, kimia, biologi matematika, dan lain-lain. Dengan membuat sendiri peta konsep siswa "melihat" bidang studi itu lebih jelas dan mempelajari bidang studi itu lebih bermakna.

2. Suatu peta konsep merupakan suatu gambar dua dimensi dari suatu bidang studi atau suatu bagian dari bidang studi. Ciri inilah yang memperlihatkan hubungan-hubungan proposisional antara konsep-konsep. Hal inilah yang membedakan belajar bermakna dari belajar dengan cara mencatat pelajaran tanpa memperlihatkan hubungan antara konsepkonsep.

3. Ciri yang ketiga adalah mengenai cara menyatakan hubungan antara konsep-konsep. Tidak semua konsep memiliki bobot yang sama. Ini berarti bahwa ada beberapa konsep yang inklusif dari pada konsep-konsep lain.

4. Ciri keempat adalah hirarki. Bila dua atau lebih konsep digambarkan di bawah suatu konsep yang lebih inklusif, terbentuklah suatu hirarki pada peta konsep tersebut.

Peta konsep memegang peranan penting dalam belajar bermakna. Oleh karena itu siswa hendaknya pandai menyusun peta konsep untuk meyakinkan bahwa siswa telah belajar bermakna. Langkah-langkah berikut ini dapat diikuti untuk menciptakan suatu peta konsep, seperti: 1) mengidentifikasi ide pokok atau prinsip yang melingkupi sejumlah konsep; 2) mengidentifikasi ide-ide atau konsep-konsep sekunder yang menunjang ide utama; 3) menempatkan ide utama 
di tengah atau di puncak peta tersebut; 4) mengelompokkan ide-ide sekunder di sekeliling ide utama yang secara visual menunjukan hubungan ide-ide tersebut dengan ide utama.

Langkah-langkah dalam memperkenalkan metode peta konsep kepada siswa sebagai berikut: 1) Siswa bersama guru memahami suatu ide, hal ini merupakan cara yang baik untuk menolong siswa belajar yang bermakna, yaitu membimbing mereka untuk melihat peranan konsep dan hubungan antara konsep yang terdapat di dalam pikiran dan lingkungan eksternal mereka; 2) Siswa dibimbing oleh guru untuk mencari konsep-konsep yang spesifik, baik dari segi materi tertulis maupun dari segi materi yang akan disampaikan secara lisan, kemudian mencari hubungan diantara konsep-konsep itu. Konsepkonsep yang dirangkaikan oleh kata-kata penghubung (linking words) merupakan unit-unit bahasa yang mengungkapkan makna yang penting; 3) Siswa ditekankan dan dimbimbing guru bahwa peta konsep mengungkapkan suatu cara menggambarkan konsep-konsep, dan hubungan diantara konsep tersebut. Manusia pada umumnya mempunyai ingatan yang kurang baik atau terbatas terhadap hal-hal yang spesifik (yang bersifat recal), disinilah peranan dari peta konsep dalam mempermudahkan pembelajaran dan mengingat kembali materi yang telah disampaikan secara baik. Peta konsep mempunyai potensi meningkatkan kemampuan manusia untuk mengenal pola-pola yang memberikan kemudahan pada sat pembelajaran.

Hasil belajar yang optimal dapat tercapai bila ada sesuatu yang diingat dan dipahami yang diperlukan untuk proses belajar selanjutnya. Dari beberapa definisi di atas bahwa peta konsep merupakan suatu cara penyajian konsep atau gagasan pokok yang disusun secara berjenjang dari yang bersifat umum menuju khusus peta konsep dilengkapi dengan garis- garis penghubung yang sesuai. Dalam peta konsep dapat ditempatkan suatu susunan yang nyata, dengan cara menghubungkan konsep-konsep yang ada. Peta konsep yang lengkap harus menyajikan konsep atau gagasan pokok dengan hubungan yang sesuai dan mengungkapkan pola pandang tunggal yang mempunyai hubungan timbal balik. Diharapkan dengan peta konsep daya ingat siswa dapat ditingkatkan. Penggunaan peta konsep dalam proses belajar mengajar lebih menuntun peran aktif para siswa.

\section{Keunggulan Metode Peta Konsep}

Menurut Buzan (2005) bahwa metode peta konsep atau Mind Map memiliki beberapa keunggulan, yaitu: 1) Mengaktifkan seluruh otak; 2) Membereskan akal dari kesusutan akal; 3) Memungkinkan kita berfokus pada pokok bahasan; 4) Membantu menunjukan hubungan antara bagian-bagian informasi yang saling terpisah; 5) Memberi gambaran yang jelas pada keseluruhan perincian; 6) Memungkinkan kita mengelompokan konsep, membantu kita membandingkannya; 7) Mengisyaratkan kita untuk memusatkan perhatian pada pokok bahasan yang membantu mengalihkan informasi tentangnya dari ingatan jangka pendek ke ingatan jangka panjang.

Secara aplikatif, strategi penerapan peta konsep dalam upaya meningkatkan hasil belajar dan kreativitas siswa, memiliki beberapa langkah sebagai berikut: (1) buatlah daftar kata-kata yang cukup dikenal oleh siswa pada papan tulis untuk objek-objek dan kejadian/peristiwa misalnya kata lingkungan alam dan lingkungan buatan; (2) tanyakanlah kepada siswa, bagaimanakah mereka menggambarkan hubungan apabila mereka mendengarkan kata lingkungan alam dan lingkungan buatan. (3) buatlah daftar kata-kata penghubung seperti adalah, dengan, berupa, sehingga, dapat. Tanyakan kepada siswa, apa saja yang mereka pikirkan tentang kata-kata tersebut. Kata-kata tersebut bukan kata-kata konsep melainkan kata penghubung bila mana dirangkaikan dengan kata konsep akan membentuk kalimat yang bermakna. (4) buatlah beberapa kalimat pendek yang menggambarkan rangkaian kata-kata konsep dan kata penghubung sehingga dapat bermakna. (5) siswa ditugaskan untuk membuat kalimat-kalimat pendek dari konsep-konsep dan kata penghubung yang diberikan. (6) pilihlah materi dari buku yang sesuai dengan penggunaan metode peta konsep, kemudian materi tersebut dibaca oleh siswa, selanjutnya siswa ditugaskan untuk mencari konsep kunci, kemudian siswa akan ditugaskan 
untuk mencatat konsep yang mereka temukan serta menghubungkan dengan kata penghubung

\section{METODE PENELITIAN}

Penelitian ini merupakan jenis penelitian tindakan kelas. Tujuan utama penelitian tindakan kelas adalah untuk meningkatkan praktek-praktek pembelajaran di kelas khususnya pada kelas $\mathrm{V}$ SD Negeri 028 Kubang Jaya. Jenis penelitian tindakan kelas yang digunakan dalam penelitian ini adalah kolaboratif, yaitu peneliti yang akan melakukan tindakan juga harus dibant oleh rekan sejawat yang berperan sebagai observer di dalam penelitian ini. Tindakan dalam penelitian ini berupa penerapan metode peta konsep dengan tujuan untuk meningkatkan hasil belajar IPS siswa kelas V. Dalam kegiatan ini semua yang tergabung dalam penelitian ini terlibat secara penuh dalam proses perencanaan, tindakan, observasi, dan refleksi.

Adapun tempat penelitian ini adalah SD Negeri 028 Kubang Jaya. Sedangkan subjek dalam penelitian ini adalah siswa kelas $\mathrm{V}$ yang berjumlah sebanyak 25 siswa.

\section{Teknik Pengumpulan Data}

Data yang dikumpulkan dalam penelitian ini adalah data observasi (data kualitatif) dan hasil tes evaluasi. Teknik pengumpulan data pada penelitian ini adalah:

\section{Observasi}

Tahap observasi sebenarnya berjalan bersamaan dengan tahap pelaksanaan tindakan. Observasi digunakan untuk mendapat data tentang pengajaran guru di dalam kelas, sehingga bias dilihat di dalam pelaksanaan pembelajaran benar-benar sesuai dengan kondisi dan proses yang diharapkan. Observasi dilakukan terhadap proses pembelajaran dengan menggunakan metode peta konsep. Pada tahap ini, guru sebagai peneliti melakukan pengamatan dan mencatat semua hal-hal yan diperlukan dan terjadi selama pelaksanaan tindakan berlangsung. Pengumpulan data ini dilakukan dengan menggunakan lembar instrument observasi atau evaluasi yang telah disusun. Termasuk juga pengamatan secara cermat pelaksanaan secara skenario pembelajaran dari waktu ke waktu dan dampaknya terhadap yang sesuai sehingga terbentuklah suatu kalimat yang bermakna.

proses dan hasil belajar siswa. Data yang dikumpulkan berupa data hasil tes dan hasil angket yang menunjukkan keaktifan kegiatan pembelajaran yang dilakukan oleh observer.

2. Tes

Tes adalah serentetan pertanyaan yang digunakan untuk mengukur ketrampilan, pengtahuan kemampuan atau bakat yang dimiliki individu atau kelompok (Arikunto, 2006: 160). Bentuk tes yang dipergunakan dalam pengumpulan data adalah berupa butir-butir soal berbentuk obyektif untuk memberikan kuis setiap akhir kegiatan pembelajaran, dan butir-butir soal berbentuk subjektif yang diberikan pada setiap akhir siklus. Tes yang dimasukan dalam penelitian ini adalah tes prestasi atau hasil belajar, yaitu tes yang digunakan untuk mengukukur pencapaian seseorang setelah mempelajari sesuatu.

Data yang dikumpulkan yaitu data prestasi belajar siswa dengan menggunakan kreteria ketuntasan minimal (KKM) pada mata pelajaran IPS apabila siswa telah mencapai nilai sama dengan atau lebih besar 65 (enam puluh lima), sesuai dengan KTSP.

\section{Teknik Analisis Data}

Analisis data hasil pengamatan didasarkan pada lembar pengamatan Selama proses pembelajaran dengan melihat kesesuian antara perencanaan dengan pelaksanaan tindakan. Pelaksanaan tindakan dinyatakan sesuai jika semua aktivitas dalam Penerapan pembelajaran pendidikan Strategi Pembelajaran Peta Konsep terlaksana dengan baik.

Adapun untuk mengetahui nilai aktivitas siswa dan guru dapat menggunakan rumus sebagai berikut :

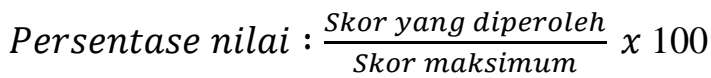
(Dekdikbud:2006) 
Sedangkan untuk mengetahui interval kategoro aktivitas guru dan siswa dapat dilihat sebagai berikut:

Tabel 1. Interval Aktivitas guru dan siswa

\begin{tabular}{cl}
\hline Interval & Kategori \\
\hline $80-100 \%$ & Amat Baik \\
\hline $70-79 \%$ & Baik \\
\hline $60-69 \%$ & Cukup \\
\hline $45-59 \%$ & Kurang \\
\hline$>44 \%$ & Amat Kurang \\
\hline
\end{tabular}

Sumber : Harun Arrasyid (2008)

Untuk menentukan ketuntasan belajar siswa digunakan instrument test hasil belajar siswa yang meliputi apektif, kognitif dan psikomotor. Penentuan ketuntasan berdasakan acuan patokan yaitu sejauh mana kemampuan yang di targetkan dapat di kuasai siswa dengan cara menghitung jumlah siswa yang menjawab benar di bagi dengan jumlah siswa seluruhnya. Rumusnya adalah :

$$
\mathrm{KB}=\frac{\mathrm{T}}{\mathrm{Tt}} \mathrm{X} 100 \%
$$

Dimana :

$$
\mathrm{KB}=\text { ketuntasan belajar }
$$

$\mathrm{T}=$ jumlah soal jawaban yang benar

$\mathrm{Tt}=$ jumlah soal seluruhnya

(sumber Trianto:241)

Adapun untuk mengetahui nilai hasil belajar dapat menggunakan interval kategori sebagai berikut:

Tabel 2. Interval Hasil Belajar Siswa

\begin{tabular}{ll}
\hline Interval & Kategori \\
\hline $80-100 \%$ & Amat Baik \\
\hline $70-79 \%$ & Baik \\
\hline $60-69 \%$ & Cukup \\
\hline $45-59 \%$ & Kurang \\
\hline$>44 \%$ & Amat Kurang \\
\hline
\end{tabular}

Sumber : Harun Arrasyid (2008)

Indicator keberhasilan penelitian ini ditandai dengan adanya peningkatan hasil belajar siswa lebih dari atau sama dengan ( $\geq)$ 75\% dari seluruh siswa tuntas belajar, yakni memperoleh nilai minimal 65 pada aspek kognitif setelah melaksanakan pembelajaran dengan menggunakan metode peta konsep sesuai KKM mata pelajaran IPS di SD Negeri 028 Kubang Jaya.

\section{HASIL DAN PEMBAHASAN}

\section{Ativitas Guru Siklus I dan Siklus II}

Pada aktivitas guru selama proses pembelajarn berlangsung mengalami peningkatan disetiap pertemuannya. Fungsi guru sangat menentukan dan mempunyai pengaruh yang sangat besar terhadap pengingkatan hasil belajar siswa. 
Untuk melihat peningkatan aktivitas guru di bawah ini: pada siklus I dan siklus II dapat dilihat pada tabel

Tabel 3. Rata-rata Aktivitas Guru Siklus I dan Siklus II

\begin{tabular}{ccccc}
\hline Siklus & Pertemuan & $\begin{array}{c}\text { Skor yang di } \\
\text { peroleh }\end{array}$ & $\begin{array}{c}\text { Nilai Persentase } \\
\text { \% }\end{array}$ & Kategori \\
\hline \multirow{2}{*}{ I } & 1 & 12 & 60 & Cukup \\
\cline { 2 - 5 } & 2 & 15 & 75 & Baik \\
\hline \multirow{2}{*}{ II } & 3 & 17 & 85 & Amat Baik \\
\cline { 2 - 5 } & 4 & 19 & 95 & Amat Baik \\
\hline
\end{tabular}

Berdasarkan analisis tabel aktivitas guru di atas, jumlah skor penilaian aktivitas guru pada pertemuan pertama sebesar 12 dengan persentase sebesar $60 \%$ kategori cukup. Pada pertemuan kedua aktivitas guru mendapat skor penilaian sebesar 15 dengan persentase sebesar $75 \%$ kategori baik. Untuk siklus II, aktivitas guru pada pertemuan ketiga mendapat skor penilaian sebesar 17 dengan persentase sebesar 85\% kategori amat baik, sedangkan pada pertemuan keempat skor aktivitas guru sebesar 19 dengan persentase sebesar 95\% kategori amat baik. Peningkatan aktivitas guru ini terjadi karena guru telah dapat menguasai langkah-langkah pembelajaran peta konsep, hal ini dibktikan oleh didalam mengajar guru telah sesuai dengan langkah-langkah pembelajaran peta konsep.

\section{Aktivitas Siswa Siklus I dan Siklus II}

Data aktivitas siswa yang diperoleh selama pembelajaran dengan menerapkan strategi peta konsep pada siklus I dan II mengalami peningkatan, hal ini dapat dilihat pada tabel di bawah ini.

Tabel 4. Rata-rata Aktivitas Siswa Siklus I dan Siklus II

\begin{tabular}{ccccc}
\hline \multirow{2}{*}{ Siklus } & Pertemuan & $\begin{array}{c}\text { Skor yang di } \\
\text { peroleh }\end{array}$ & $\begin{array}{c}\text { Rata-rata } \\
\text { pertemuan }\end{array}$ & Kategori \\
\hline \multirow{2}{*}{ I } & 1 & 13 & 65 & Cukup \\
\cline { 2 - 5 } & 2 & 14 & 70 & Baik \\
\hline \multirow{2}{*}{ II } & 3 & 16 & 80 & Amat Baik \\
\cline { 2 - 5 } & 4 & 18 & 90 & Amat Baik \\
\hline
\end{tabular}

Berdasarkan analisis tabel aktivitas siswa di atas, jumlah skor penilaian aktivitas siswa pada pertemuan pertama sebesar 13 dengan persentase sebesar $65 \%$ kategori cukup. Pada pertemuan kedua aktivitas siswa mendapat skor penilaian sebesar 14 dengan persentase sebesar $70 \%$ kategori baik. Untuk siklus II, aktivitas guru pada pertemuan ketiga mendapat skor penilaian sebesar 16 dengan persentase sebesar 80\% kategori amat baik, sedangkan pada pertemuan keempat skor aktivitas guru sebesar 18 dengan persentase sebesar 90\% kategori amat baik. Peningkatan aktivitas siswa ini terjadi karena siswa telah dapat menguasai langkah-langkah pembelajaran peta konsep dengan baik, selain itu siswa di dalam proses pembelajaran telah mennjukan keaktipannya sehingga siswa mampu menjawab pertanyaan dari guru. Hasil ini membuktikan bahwa penerapan peta konsep mampu meningkatkan aktivitas siswa.

\section{Hasil Belajar Siswa Siklus I dan Siklus II}

Hasil belajar siswa yang diukur berdasarkan ketuntasan belajar pada UAS I dan UAS II menunjukkan bahwa ketuntasan individu dan klasikal hasil belajar siswa pada siklus I dan siklus II mengalami peningkatan sebagaimana yang terlihat pada tabel dibawah ini: 
Tabel 5. Ketuntasan Individu dan klasikal Pada Siklus I dan II

\begin{tabular}{lccccc}
\hline Siklus & $\begin{array}{c}\text { Siswa Yang } \\
\text { Hadir }\end{array}$ & $\begin{array}{c}\text { Kiswa } \\
\text { Tuntas }\end{array}$ & $\begin{array}{c}\text { Siswa Tidak } \\
\text { Tuntas }\end{array}$ & $\begin{array}{c}\text { Persen } \\
\text { Ketuntasan }\end{array}$ & Kategori \\
\hline Skor Dasar & 25 & 11 & 14 & $44 \%$ & Amat Kurang \\
\hline Siklus I & 25 & 18 & 7 & $72 \%$ & Baik \\
\hline Siklus II & 25 & 22 & 3 & $88 \%$ & Amat Baik \\
\hline
\end{tabular}

Dari tabel hasil belajar siswa di atas menunjukan bahwa, dilihat dari skor dasar siswa, siswa yang tuntas sebesar 11 orang (44\%) dan tidak tuntas sebanyak 14 orang $(56 \%)$. Setelah dilakukan siklus I dan II dengan menerapkan model pembelajaran peta konsep hasil belajar siswa mengalami peningkatan. Hal ini terlihat dari hasil penilaian siklus I UAS I, siswa yang tuntas sebanyak 18 orang siswa (72\%) dan tidak tuntas sebanyak 7 orang siswa (28\%). Sedangkan pada siklus II UAS II, siswa yang tuntas sebanyak 22 orang $(88 \%)$ dan yang tidak tuntas sebanyak 3 orang $(12 \%)$. Jadi ketuntasan belajar individu meningkat dimana jumlah siswa yang mencapai

\section{SIMPULAN DAN REKOMENDASI}

Berdasarkan data yang diperoleh di atas dapat peneliti simpulkan bahwa dengan menerapkan metode peta konsep dapat meningkatkan hasil belajar IPS siswa kelas V SD Negeri 028 Kubang Jaya. Adapun peningkatannya dapat dilihat sebagai berikt:

1. Aktivitas Guru; Peningkatan ini juga memberikan hasil terjadinya peningkatan pada aktivitas guru. Pada siklus I pertemuan 1, ratarata $60 \%$, pertemuan ke 2 rata-rata $75 \%$. Pada siklus II pertemuan 3 rata-rata $85 \%$, pertemuan ke II rata-rata $95 \%$.

2. Aktivitas Siswa; Aktivitas siswa meningkat juga dalam pembelajaran. Pada siklus I pertemuan 1 rata-rata $65 \%$, pertemuan ke 2 rata-rata $70 \%$. Pada siklus II pertemuan 3 ratarata $80 \%$, pertemuan ke 3 rata-rata $90 \%$.

3. Hasil Belajar Siswa; Dilihat dari skor dasar siswa, siswa yang tuntas sebesar 11 orang (44\%) dan tidak tuntas sebanyak 14 orang (56\%). Setelah dilakukan siklus I dan II dengan menerapkan model pembelajaran peta ketuntasan semakin bertambah sampai pada UAS II siklus II. Bahwa ketuntasan belajar secara individu telah terpenuhi, bila setiap individu telah mencapai $65 \%$ dari jumlah soal yang diberikan atau dengan nilai 65 , maka siswa dikatakan tuntas dari materi yang diajarkan dan dikuasai oleh masing-masing siswa.

Peningkatan hasil belajar siswa disebabkan oleh, pembelajaran menggunakan peta konsep dapat membantu guru memahami macam-macam konsep yang terdapat dalam topik yang akan diajarkan dan memperoleh wawasan baru, selain itu peta konsep dapat membantu guru dalam menghindari miskonsepsi oleh siswa.

konsep hasil belajar siswa mengalami peningkatan. Hal ini terlihat dari hasil penilaian siklus I UAS I, siswa yang tuntas sebanyak 18 orang siswa $(72 \%)$ dan tidak tuntas sebanyak 7 orang siswa (28\%). Sedangkan pada siklus II UAS II, siswa yang tuntas sebanyak 22 orang (88\%) dan yang tidak tuntas sebanyak 3 orang (12\%).

Berdasarkan simpulan penelitian, peneliti merekomendasikan beberapa hal yang terkait dengan hasil penelitian sebagai berikut:

1. Bagi guru, sebaiknya memanfaatkan peta konsep dalam proses pembelajaran sebagai salah satu strategi pembelajaran IPS guna untuk meningkatkan hasil belajar siswa di sekolah.

2. Bagi sekolah, sebagai bahan masukan untuk meningkatkan kualitas keberhasilan pengajaran di sekolah sehingga dapat meningkatkan mutu pendidikan terutama pada pembelajaran IPS.

3. Bagi peneliti, yang ingin mengadakan 
penelitian lebih lanjut dengan menggunakan penerapan strategi peta konsep agar sebelumnya mempersiapkan segala sesuatu yang berhubungan dengan materi pelajaran

\section{DAFTAR PUSTAKA}

Al Rasyid, H. (2008). Dasar-Dasar Statistika Terapan. Bandung: program pascasarjana UNPAD.

Arikunto, S. (2006). Prosedur Penelitian Suatu Pendekatan Praktik. Jakarta: Rineka Cipta

Buzan, T. (2005). Buku Pintar Mind Mapping, Jakarta: Gramedia.

Depdiknas. (2006). Permendiknas No 22 Tahun 2006 Tentang Standar Isi. Jakarta : Depdiknas.

Erita, T. (2017). Meningkatkan Penguasaan Belajar IPS Melalui Strategi Ekspositori Siswa Kelas VI SDN 01 Tanjuang Balik Kecamatan Pangkalan Koto Baru Kabupaten Lima Puluh Kota Sumatera Barat. Jurnal PAJAR (Pendidikan dan Pengajaran), 1(2), 240-246.

Kardi. (1997). Pengajaran Langsung. Surabaya: Universitas Negeri Surabaya.

Khoir, M. (2012). Paradigma Pendidikan IPS di Indonesia.

Online yang akan diajarkan, sehingga diperoleh hasil yang maksimal https://mazidatulkhoir.wordpress.com/categ ory/sosial.

Mukmin. (2018). Penerapan Strategi Belajar Peta Konsep ntuk Meningkatkan Hasil Belajar IPS Siswa Kelas V Sekolah Dasar. Jurnal PAJAR (Pendidikan dan Pengajaran), 7(1), 149-1158.

Saifullah, M.T. (2017). Penerapan Model Pembelajaran Kooperatif Tipe Numbered Heads Together untuk Meningkatkan Hasil Belajar IPS Siswa Kelas VI SD Negeri 007 Pendalian Kecamatan Pendalian IV Koto Kabupaten Rokan Hulu. Jurnal PAJAR (Pendidikan dan Pengajaran), 1(2), 324332.

Trianto. (2010). Model Pembelajaran Terpadu, Konsep, Strategi dan Implementasinya dalam KTSP. Jakarta: Bumi Aksara.

Undang-Undang RI No. 20 Tahun 2003 tentang SISDIKNAS. 